

\title{
The blood platelets contribution to innate host defense - what they have learned from their big brothers
}

\author{
Matthias Klinger
}

\section{To cite this version:}

Matthias Klinger. The blood platelets contribution to innate host defense - what they have learned from their big brothers. Biotechnology Journal, 2009, 4 (6), pp.914. 10.1002/biot.200800362 . hal00490110

\section{HAL Id: hal-00490110 https://hal.science/hal-00490110}

Submitted on 8 Jun 2010

HAL is a multi-disciplinary open access archive for the deposit and dissemination of scientific research documents, whether they are published or not. The documents may come from teaching and research institutions in France or abroad, or from public or private research centers.
L'archive ouverte pluridisciplinaire HAL, est destinée au dépôt et à la diffusion de documents scientifiques de niveau recherche, publiés ou non, émanant des établissements d'enseignement et de recherche français ou étrangers, des laboratoires publics ou privés. 


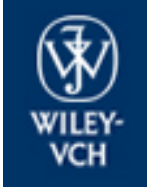

Biotechnology Journal

\section{The blood platelets contribution to innate host defense - what they have learned from their big brothers}

\begin{tabular}{|r|l|}
\hline Journal: & Biotechnology Journal \\
\hline Manuscript ID: & biot.200800362.R1 \\
\hline Wiley - Manuscript type: & Research Article \\
\hline Date Submitted by the \\
Author: & 01-May-2009 \\
\hline Complete List of Authors: & Klinger, Matthias; University of Lübeck, Institute of Anatomy \\
\hline Keywords: & $\begin{array}{l}\text { blood platelets, innate immunity, blood plasma, thrombin, reactive } \\
\text { oxygen species }\end{array}$ \\
\hline
\end{tabular}

\section{scholarONE" \\ Manuscript Central}




\begin{abstract}
Bactericidal effects of blood platelets have been known for more than 120 years, but the underlying mechanisms are largely obscure. Keeping in mind structural and functional analogies of platelets to neutrophiles, three different mechanisms are thinkable: Engulfment of pathogens, release of microbicidal proteins, and production of reactive oxygen species (ROS). Here, we focus on the release of ROS and a possible contribution of blood plasma and thrombin to the bactericidal effects.

Killing of bacteria was evaluated by DNA fluorescence labeling and electron microscopy. Release of ROS by platelets was measured photometrically by cytochrome $\mathrm{C}$ and phenolred/peroxidase assays and was further evaluated by topological methods. We found that (1) platelets produce 1500 times less $\mathrm{O}_{2}{ }^{-}$and 4000 times less $\mathrm{H}_{2} \mathrm{O}_{2}$ compared to neutrophils, (2) ROS do not effect the killing rates, (3) no local enrichment of ROS was detectable. On the other hand, thrombin and plasma proteins with a MW >100 kDa are essential for bactericidal effects.

We suggest that platelets contribute to the innate host defence by providing a catalytical surface for synthesis of thrombin. In the presence of a heat-instable plasma protein, thrombin may generate a strong bactericidal complex, which is only effective in close vicinity to the platelet membrane.
\end{abstract}




\section{Introduction}

Platelets are primarily known for their crucial role in haemostatic processes but they do have far more functions. They play a role in inflammation by quickly reacting to various specific signals and releasing inflammatory mediators [1]. They modulate vascular reactions, release mediators for chemotaxis and stimulation of leukocytes, and participate in wound repair by release of PDGF, Angiopoietin or EGF [1]. In this way, platelets chip into all stages of inflammation.

Inflammation is often the consequence of invading pathogens, and it seems to be logical that platelets participate in antimicrobial host defense as they are the first cellular elements in the blood that accumulate at any site of a vascular lesion [2-4]. Various bacteria bind to platelets [5-7] and are embedded and killed in platelet aggregates [8;9]. The binding of bacteria can be a direct one via receptors or can be indirect via a bridging molecule like fibrinogen [10].

Although a bactericidal function of platelets has been described for more than 120 years now, the underlying mechanisms are not clear [11]. Analogous to neutrophils, there are 3 potential killing mechanisms that may be proposed to operate in platelets: 1. platelets store and process bactericidal peptides, 2 . they have a phagocytic capacity, and 3. they synthesize reactive oxygen species (ROS). As summarized below, mechanisms 1 and 2 have been under intensive investigation for longer times, but the possible role of ROS in killing bacteria by platelets has not been studied so far and stimulated the present study.

In 1972 Nachman and Weksler detected bactericidal peptides in platelet granules [4]. They were identified and described in detail in rabbits by Yeaman et al.[12] and later on in humans by Krijgsveld et al.[13] and Tang et al.[14]. But Tang et al. reported about conflicting data on bactericidal activities of purified peptides, possibly due to inhibitory effects of sodium phosphate [14], which is also used in our experiments. Moreover, Krijgsveld et al.[13] needed 100 -fold higher platelet concentrations to extract thrombocidins in bactericidal amounts than we used in our killing model. Therefore we asked if additional mechanisms exist that are responsible for the observed strong killing effects and one of them could be phagocytosis. Platelets show three main phagocytic features that are typical for leucocytes [4;15]: they interact with particulate material, they contain lysosomes in the cytoplasm and they store inflammatory mediators. But true phagocytosis of bacteria, which means that the vacuoles have no permanent contact to the extracellular space, is not established in platelets yet.

Platelets enclose bacteria trapped within an aggregate or act as "covercytes" by covering the bacterial surface [16]. They also may take up bacteria into the open canalicular system $[3 ; 16]$. 
White [16] concluded that bacteria-platelet interaction occurs spontaneously after prolonged incubation times or prestimulation of platelets. Since enclosing by platelets does not seem to alter bacteria morphologically, it is questionable if this mechanism of ingestion is bactericidal. And finally, platelets could have the possibility to kill bacteria by synthesis of ROS [17-24], which act as potent killing agents with particularly high efficacy in leukocytes [25]. In this way, neutrophils and macrophages increase oxygen consumption during phagocytosis in what has been termed respiratory burst [26]. It was observed that ROS production in neutrophils and osteoclasts may be locally restricted to areas of "ruffled membranes" [27;28]. Since we found these ruffled membranes also in platelets, especially at platelet-bacteria binding sites [9], we assumed that platelets could kill bacteria by the local release of ROS. Keeping in mind the analogies to neutrophils, we always investigated the ROS release by platelets and neutrophils simultaneously, taking the latter "big brothers" as the positive control. Thus, we asked if ROS production in platelets is high enough to kill bacteria in general and if not so, if locally restricted ROS release might explain the observed killing effects. Since the amount of ROS released by platelets was not sufficient alone to explain the bactericidal effects, we further investigated the role of plasma proteins and the effect of thrombin in the observed killing model.

We tested the killing potential of gel-filtered platelets (plasma-free) in buffer and determined the killing rates after adding increasing plasma portions, furthermore after addition of heatinactivated plasma and after the addition of high $(>100 \mathrm{kDa})$ and low $(<100 \mathrm{kDa})$ molecular weight plasma protein fractions.

Thrombin performs its platelet stimulation in humans via the protease activating receptors (PAR) 1 and 4 on the platelet surface [29;30] but also cleaves plasma proteins to generate fibrin [31].

Because the addition of thrombin was crucial to get bactericidal effects, we dissected the action of thrombin by selecting the stimulation of the protease activating receptors (PAR) 1 and 4 on the platelet surface. We activated PAR 1 with the synthetic thrombin receptor agonist SFLLRN [32] and the PAR 4 with GYPGKF [33], and determined the killing rates. Furthermore, we mimicked the proteolytical function of thrombin by the addition of trypsin, we inhibited thrombin activity by hirudin, and compared all killing rates. 


\section{Materials and Methods}

\section{Platelet and neutrophil preparation}

Buffy coats (BC) or platelet concentrates (PC) were collected from healthy donors after informed consent and were kindly provided by Dr. Peter Schlenke from the Department of Immunology and Blood Transfusion, University of Luebeck.

For photometric assays and fluorescence microscopy, $\mathrm{BC}$ were prepared by centrifugation (Optipac PL-146/Optipress, Baxter). Platelet-rich plasma was isolated by centrifugation of BC for $15 \mathrm{~min}$ at $160 \mathrm{x} \mathrm{g}$ and was allowed to rest for $20 \mathrm{~min}$ to recover from the trauma of centrifugation and compaction. PC were then obtained by centrifugation of platelet-rich plasma for $10 \mathrm{~min}$ at $1000 \mathrm{x}$ g. Platelets were resuspended in Tyrode buffer, containing $138 \mathrm{mM} \mathrm{NaCl}, 2.7 \mathrm{mM} \mathrm{KCl}, 12 \mathrm{mM} \mathrm{NaHCO}_{3}, 5 \mathrm{mM}$ HEPES, $0.4 \mathrm{mM} \mathrm{Na}_{2} \mathrm{HPO}_{4}, 1 \mathrm{mM}$ $\mathrm{MgCl}_{2}$ and $5 \mathrm{mM}$ glucose [19]. The number of contaminating leukocytes was $<0.1 \%$. Neutrophils were separated from other cells in the BC using a Histopaque $1077^{\circledR}$ gradient centrifugation (Sigma, Schnelldorf, Germany) for $30 \mathrm{~min}$ at $400 \mathrm{x}$ g followed by a subsequent ammonium chloride haemolysis [34]. Neutrophils were resuspended in RPMI $1640^{\circledR}$ medium (Sigma) and were counted in a Neubauer chamber.

For Killing assays, PC were prepared by plateletpheresis (Amicus ${ }^{\circledR}$ cell separator, Baxter). Platelet counts were adjusted to $6 \times 10^{8} / \mathrm{ml}$. PC were stored for a maximum of 3 days at $22^{\circ} \mathrm{C}$ under constant agitation for better gas exchange and prevention of clumping.

Gel-filtered platelets were obtained by spinning down PC for $12 \mathrm{~min}$ at $1200 \mathrm{x}$ g onto a $50 \%$ albumin cushion [35]. Platelets were collected and resuspended in HEPES buffer containing $0.35 \%$ BSA, $137 \mathrm{mM} \mathrm{NaCl}, 2.7 \mathrm{mM} \mathrm{KCl}, 3 \mathrm{mM} \mathrm{Na}_{2} \mathrm{HPO}_{4}, 1 \mathrm{mM} \mathrm{MgCl} 2,5.5 \mathrm{mM}$ glucose and 3.5 mM HEPES and then applied to a Sepharose 2B column (Sigma).

\section{Bacteria suspensions}

Bacillus subtilis (B. subtilis), Escherichia coli (E. coli) and Staphylococcus aureus (S. aureus) were grown on tryptone-soya agar plates (Oxoid, Wesel, Germany) at $37^{\circ} \mathrm{C}$ for $16 \mathrm{~h}$. For killing experiments, bacteria were collected and suspended in $0.9 \%$ sodium chloride to $10^{9}$ bacteria/ml.

\section{Plasma preparation and fractionation}

Human plasma was obtained by centrifugation of PC for $90 \mathrm{sec}$ at $14000 \mathrm{x} \mathrm{g}$. To prepare heat-inactivated plasma, the obtained plasma were incubated for $20 \mathrm{~min}$ at $56^{\circ} \mathrm{C}$. To 


\section{Platelet stimulation and inhibition}

To achieve maximum killing rates, platelets were stimulated with thrombin (Sigma) at a concentration of $2 \mathrm{U} / \mathrm{ml}$ for $10 \mathrm{~min}$ at $37^{\circ} \mathrm{C}$. Inhibition of thrombin was performed by hirudin (Sigma) at a concentration of 5 antithrombin units $/ \mathrm{ml}$.

To stimulate the NAD $(\mathrm{P}) \mathrm{H}$-oxidase, we used phorbol myristate acetate (PMA, Sigma) at concentrations up to $1 \mu \mathrm{M}$. To block the $\mathrm{NAD}(\mathrm{P}) \mathrm{H}$-oxidase, we used the unspecific NAD(P)H-oxidase inhibitor Diphenylene iodonium chloride (DPI; Sigma, 50-500 nM). Cells were preincubated with DPI for 30 min before any stimulation, and DPI was also present in the incubation medium.

For selective stimulation of the thrombin receptors, we stimulated PAR 1 with SFLLRN (SF, Sigma, $75 \mu \mathrm{M}$ ) and PAR 4 with GYPGKF (GYP, Sigma, $750 \mu \mathrm{M}$ ). To mimic a proteolytical action of thrombin, we used trypsin (Sigma, $64000 \mathrm{U} / \mathrm{ml}$ ).

\section{Superoxide assay}

The superoxide $\left(\mathrm{O}_{2}^{-}\right)$production was measured by the reduction of cytochrom $\mathrm{C}$ as described by Krötz et al. [19]. Platelets were stimulated with PMA and thrombin or inhibited by DPI. After incubation times of $15 \mathrm{~min}$ (neutrophils) or $30 \mathrm{~min}$ (platelets) at $37^{\circ} \mathrm{C}$, the absorbance of the supernatants was measured with the spectrometer (Spectronic 20 Genesis) at $550 \mathrm{~nm}$. The $\mathrm{O}_{2}{ }^{-}$dependent part of cytochrome $\mathrm{C}$ reduction was calculated from the absorbance difference between samples with or without addition of superoxide dismutase (SOD, $380 \mathrm{U} / \mathrm{ml}$ ). The tests were performed in triplicates. The data were translated into nanomole $(\mathrm{nM})$ of $\mathrm{O}_{2}{ }^{-}$using the extinction coefficient of $\mathrm{E}_{550 \mathrm{nM}}=29.5 \mathrm{mM}^{-1} \mathrm{x} \mathrm{cm}^{-1}$.

\section{Hydrogen peroxide assay}


The rate of hydrogen peroxide $\left(\mathrm{H}_{2} \mathrm{O}_{2}\right)$ production was detected by the peroxidase/phenolred assay as described by Cabanis et al. [34]. Cells were incubated for $30 \mathrm{~min}$ (neutrophils) or $45 \mathrm{~min}$ (platelets) at $37^{\circ} \mathrm{C}$ in the presence of $17 \mathrm{U} / \mathrm{ml}$ horseradish-peroxidase (Sigma) and $0.2 \mathrm{mg} / \mathrm{ml}$ phenolred in buffer. After addition of $\mathrm{NaOH}$ the absorbance in the supernatant was measured at $610 \mathrm{~nm}$. The tests were performed in triplicate. Concentrations of $\mathrm{H}_{2} \mathrm{O}_{2}$ were calculated by means of a standard curve ranging till $0.6 \mu \mathrm{mol} / 1$. To additionally detect released $\mathrm{O}_{2}^{-}$, we applied superoxide dismutase (SOD), which catalyzes the conversion of $\mathrm{O}_{2}{ }^{-}$ into $\mathrm{H}_{2} \mathrm{O}_{2}$.

\section{Topological detection of $\mathrm{H}_{2} \mathrm{O}_{2}$ by fluorescence microscopy}

Cells were dropped on prewarmed slides to adhere. After washing with phosphate buffered saline (PBS), $10 \mu \mathrm{M}$ of the fluorescence dye Oxyburst Green $\mathrm{H}_{2} \mathrm{HFF}^{\circledR}$ (Molecular Probes, Eugene, Oregon) was added. Cells were stimulated by $0.5 \mu$ M of PMA (Sigma), $160 \mathrm{mg} / \mathrm{l}$ horseradish-peroxidase were added, and samples were incubated for $30 \mathrm{~min}$. Samples were washed with PBS and were imaged using the confocal laser scanning microscope (LSM 510 Meta, Zeiss, Jena, Germany). The microscope was operated at $488 \mathrm{~nm}$ excitation, and a 510$580 \mathrm{~nm}$ emission filter was used.

\section{Topological detection of $\mathrm{H}_{2} \mathrm{O}_{2}$ by electron microscopy}

Cerium chloride reacts with $\mathrm{H}_{2} \mathrm{O}_{2}$ to form ceriumperhydroxide, which precipitates in the form of electron dense crystals at the side of $\mathrm{H}_{2} \mathrm{O}_{2}$ synthesis [36]. Neutrophils or platelets were incubated on Thermanox ${ }^{\circledR}$ Plastic Coverslips (Nunc, Wiesbaden, Germany ) for 30 min in the presence of cerium chloride $\left(\mathrm{CeCl}_{3}, 10 \mathrm{mM}\right.$, Sigma), with or without $1 \mu \mathrm{M}$ PMA and $B$. subtilis. Cells were diluted in ringer lactate solution (Fresenius, Bad Homburg, Germany) with addition of $5 \mathrm{mM}$ glucose according to Telek et al. [37]. Samples were fixed with $2.5 \%$ glutaraldehyde for $2 \mathrm{~h}$ and were washed in $0.1 \mathrm{M}$ cacodylate puffer, $\mathrm{pH}$ 7.2. Postfixation was performed with $1 \%$ osmiumtetroxide $\left(\mathrm{OsO}_{4}\right)$. Samples were dehydrated in ethanol and embedded in araldite (Fluka, Buchs, Switzerland). Ultrathin sections were stained with uranyl acetate and lead citrate and were viewed with a Philips EM 400.

\section{Killing assays}

For quantitative detection of dead bacteria, we used DNA double labelling with the fluorescence dye LIVE/DEAD ${ }^{\circledR}$ BacLight $^{\text {TM }}$ (Molecular Probes, Eugene, USA). The rate of 


\section{Statistics}

All data are expressed as mean \pm standard deviation (SD). Statistical significance $(\mathrm{p}<0.05)$ was determined by using the Wilcoxon rank sum test performed by JMP® software (SAS Institute) and was characterized at the figures by an asterisk $(*)$. 


\section{Results}

Killing rates of $B$. subtilis, $E$. coli and $S$. aureus diverge

Thrombin-stimulated platelets in plasma are capable to kill B. subtilis and E. coli up to $97 \%$, but were not able to kill $S$. aureus. All following killing tests were performed with the most susceptible bacteria, B. subtilis, which also yielded the brightest fluorescence labeling.

\section{$\mathrm{O}_{2}^{-}-$production in platelets is very low compared to neutrophils}

To see if platelets release ROS in bactericidal amounts, we first investigated the $\mathrm{O}_{2}{ }^{-}$release photometrically. Platelets produce a small and hardly detectable amount of superoxide. Resting platelets show a basal production of $0.2 \pm 0.27 \mu \mathrm{M} \mathrm{O}_{2}^{-} / \mathrm{min} / 7 \times 10^{8}$ platelets $(\mathrm{n}=9)$. Stimulation with $1 \mu \mathrm{M}$ PMA led to a 2.4-fold increase of $\mathrm{O}_{2}{ }^{-}$release on average $(0.47 \pm 0.46$ $\left.\mu \mathrm{M} \mathrm{O}_{2}{ }^{-}\right)$. Thrombin $\left(2 \mathrm{U} / \mathrm{ml}\right.$ ) led to an even lower increase of $\mathrm{O}_{2}{ }^{-}$production up to 1.5 -fold, again in only some preparations $\left(0.33 \pm 0.14 \mu \mathrm{M} \mathrm{O}_{2}^{-}, \mathrm{n}=5\right)$.

In general, no stimulators were able to induce platelet $\mathrm{O}_{2}{ }^{-}$formation significantly, since platelets of some donors did not respond. If platelet stimulation with PMA was performed in the presence of the unspecific $\mathrm{NAD}(\mathrm{P}) \mathrm{H}$-oxidase inhibitor DPI, we observed a tendency of decreasing $\mathrm{O}_{2}{ }^{-}$production from $0.47 \pm 0.46 \mu \mathrm{M}$ to $0.34 \pm 0.51 \mu \mathrm{M} \mathrm{O}_{2}{ }^{-}$.

In contrast, neutrophils strongly respond to PMA. One neutrophil produced about 1500-fold more $\mathrm{O}_{2}{ }^{-}$after PMA stimulation compared to one platelet. By addition of DPI, the maximum $\mathrm{O}_{2}{ }^{-}$release was reduced from $1.58 \pm 0.17 \mu \mathrm{M} \mathrm{O}_{2}{ }^{-} / \mathrm{min} / 10^{6}$ neutrophils to $0.66 \pm 0.08 \mu \mathrm{M}$ ( $\mathrm{p}<0,001$, Wilcoxon, $\mathrm{n}=5$ ). Thrombin had no effect on neutrophils (Fig.1).

\section{Low $\mathrm{H}_{2} \mathrm{O}_{2}$-formation in platelets in contrast to neutrophils}

$\mathrm{O}_{2}{ }^{-}$is unstable and has a short half live time in the millisecond range. It is converted into $\mathrm{H}_{2} \mathrm{O}_{2}$, which is detectable with the phenolred/peroxidase assay. Resting platelets produce $80 \pm 50 \mathrm{nM} \mathrm{H}_{2} \mathrm{O}_{2} / \mathrm{min} / 10^{9}$ platelets ( $\left.\mathrm{n}=5\right)$. Following stimulation with $1 \mu \mathrm{M}$ PMA, platelets release significantly more $\mathrm{H}_{2} \mathrm{O}_{2}\left(115 \pm 30 \mathrm{nM} \mathrm{H}_{2} \mathrm{O}_{2}, \mathrm{p}=0.03\right.$, Wilcoxon). Addition of DPI holds the $\mathrm{H}_{2} \mathrm{O}_{2}$ basal release to $64 \pm 41 \mathrm{nM}$. SOD converts generated $\mathrm{O}_{2}{ }^{-}$into $\mathrm{H}_{2} \mathrm{O}_{2}$. Thus the addition of SOD in this assay can detect indirectly the $\mathrm{O}_{2}{ }^{-}$release, too. In the presence of SOD, PMA stimulation fails to further enhance the $\mathrm{H}_{2} \mathrm{O}_{2}$ production (Fig. 2) These findings correspond to the low detection of $\mathrm{O}_{2}^{-}$in the cytochrome $\mathrm{C}$ assay (Fig. 1).

In contrast to platelets, neutrophils produce about 4000 -fold more $\mathrm{H}_{2} \mathrm{O}_{2}$ on a single cell basis. $1 \mu$ M PMA increases the $\mathrm{H}_{2} \mathrm{O}_{2}$ production from $134 \pm 36 \mathrm{nM} \mathrm{H}_{2} \mathrm{O}_{2} / \mathrm{min} / 10^{5}$ neutrophils up to $219 \pm 22 \mathrm{nM}$ ( $\mathrm{p}<0.001$, Wilcoxon). DPI reduces the basal production to $25 \pm 15 \mathrm{nM}$. 
Coincubation with SOD further enhances the maximum $\mathrm{H}_{2} \mathrm{O}_{2}$ production from $219 \pm 22 \mathrm{nM}$ to $260 \pm 15 \mathrm{nM}$ (Fig.2).

\section{Topological fluorescence analysis of $\mathrm{H}_{2} \mathrm{O}_{2}$-production by platelets}

Since the level of ROS in the supernatant is not able to reflect a possible local enrichment of ROS, we tried to identify ROS topologically by fluorescence microscopy. PMA-stimulated neutrophils showed very bright fluorescent dots, likely phagolysosomes (Fig. 3A). If platelets were stimulated with PMA, we found a very weak fluorescence signal surrounding some aggregated platelets (Fig. 3B). At bacteria-platelet-binding sites, no particular $\mathrm{H}_{2} \mathrm{O}_{2}$ signal was detectable.

\section{No colocalization of $\mathrm{H}_{2} \mathrm{O}_{2}$ - production and killing of bacteria}

Since fluorescence detection was unable to demonstrate any locally restricted ROS-synthesis in platelets, we further tried to detect $\mathrm{H}_{2} \mathrm{O}_{2}$-release by ceriumperhydroxide precipitation as visualized by electron microscopy.

As reported by Repine et al. [38], in PMA-stimulated neutrophils the external surface of the plasma membrane was coated with a thick layer of electron dense material representing this precipitation. To assure about the validity of the $\mathrm{H}_{2} \mathrm{O}_{2}$ detection by the $\mathrm{CeCl}_{3}$ method, we added catalase to the activated neutrophils. Catalase abolishes the released $\mathrm{H}_{2} \mathrm{O}_{2}$. Following addition of catalase, PMA-activated neutrophils showed no ceriumperhydroxide crystals on the plasma membrane. Unstimulated neutrophils displayed ceriumperhydroxide crystals only at a few sites.

In coincubation experiments of PMA-stimulated neutrophils with B. subtilis, most bacteria were phagocytosed. Within vacuoles of some neutrophils, ceriumperhydroxide crystals are seen, which indicates the local synthesis of $\mathrm{H}_{2} \mathrm{O}_{2}$ (Fig. 4 A-D).

In contrast to neutrophils, platelets never showed any ceriumperhydroxide crystals at the plasma membrane, regardless of any stimulation. Although a lot of viable and dead B. subtilis were enclosed in platelet aggregates or in platelets themselves, no electron dense material was detectable at binding sites of $B$. subtilis, suggesting that no $\mathrm{H}_{2} \mathrm{O}_{2}$ was produced at these sites (Fig.4 E-H).

\section{Promoting platelet ROS-generation does not lead to higher killing rates}

B. subtilis is highly susceptible to thrombin-stimulated platelets with killing rates to nearly $100 \%$ within 10 min. We compared these killing rates with those achieved following PMAstimulation of platelets. PMA does not yield any significant killing effect within $10 \mathrm{~min}$ 
(13 $\pm 6 \%$ versus baseline $8 \pm 3 \%, p>0.05$, Wilcoxon). After 20,30 and 45 min incubation time, the PMA-stimulated platelets only reached a moderate killing up to $50 \pm 20 \%$, which was significantly higher than the control but did not reach the killing efficacy of stimulation with thrombin (Fig. 5, p<0.001, Wilcoxon, n=5).

\section{Inhibition of $\mathrm{O}_{2}^{-}$does influence killing rates partially}

To determine if the killing is ROS dependent, we also inhibited the superoxide generating NAD(P)H-oxidase by preincubation of cells with DPI. When thrombin was used as a stimulator, the preincubation with DPI $(0.1 \mathrm{mM})$ leads to a tendency of decreased killing of B. subtilis within $10 \min (80 \pm 20 \%$ versus $92 \pm 5 \%, \mathrm{p}=0.2$, Wilcoxon) and was significantly decreased after $20 \min (68 \pm 24 \%$ versus $87 \pm 10 \%, p=0.009$, Wilcoxon $)$ and after $45 \min (74 \pm 20 \%$ versus $95 \pm 6 \%, p=0.0006$, Wilcoxon, $n=5)$.

If DPI-preincubated platelets are stimulated with PMA, the rate of dead bacteria vary slightly from $13 \pm 6 \%$ (PMA) to $21 \pm 7 \%$ (DPI/PMA) after $10 \mathrm{~min}(\mathrm{n}=5)$. After 20 and $30 \mathrm{~min}$ incubation, there was the same killing rate with or without DPI. Only after 45 min the killing rate decreased significantly from $50 \pm 20 \%$ (PMA) to $40 \pm 16 \%$ (DPI/PMA; $\mathrm{p}=0.03$, Wilcoxon, $n=5)$.

\section{$\mathrm{H}_{2} \mathrm{O}_{2}$-addition at platelet synthesis levels is not bactericidal to $\mathrm{B}$. subtilis}

To determine at which $\mathrm{H}_{2} \mathrm{O}_{2}$-concentrations $B$. subtilis is killed, we established a doseresponse relationship in the range from 0.05 to $50 \mathrm{mM} \mathrm{H}_{2} \mathrm{O}_{2}$. Since B. subtilis is catalase positive [39], it is relatively resistant against ROS. At concentrations up to $5 \mathrm{mM}$ we observed no bactericidal effect on $B$. subtilis ( $11 \pm 5 \%$ versus $11 \pm 3 \%$ of dead bacteria in controls). At concentrations of $50 \mathrm{mM} \mathrm{H}_{2} \mathrm{O}_{2}$ we observed only $25 \pm 1 \%$ killed bacteria $(\mathrm{n}=3)$. With a synthesis of $1 \mu \mathrm{M} \mathrm{H}_{2} \mathrm{O}_{2}$ in $10 \mathrm{~min}$, platelet concentrates only produce less than $1 / 10^{5}$ of $\mathrm{H}_{2} \mathrm{O}_{2}$ that would be needed for effective killing of this bacteria.

\section{Killing rates are dependent on addition of plasma}

Blood plasma contains many adhesive proteins, which could enhance the binding of bacteria to platelets and thereby change the rate of killing. To determine the role of plasma components in the bactericidal mechanism of platelets, we used gel-filtered platelets with addition of increasing plasma portions.

Thrombin-stimulated platelets in buffer killed only $22 \pm 22 \%$ of the added bacteria, which was significantly less than the maximum control in plasma $(\mathrm{p}<0.001$, Wilcoxon, $n=3)$. But 
already a proportion of $20 \%$ plasma completely regains the bactericidal effect (100\%). If the plasma was heat-inactivated, no killing was observed ( $8 \pm 3 \%$ versus baseline $11.1 \pm 2.8 \%$ ).

\section{Plasma but not Serum is bactericidal after addition of thrombin}

Because plasma seemed to be crucial for yielding high killing rates of $B$. subtilis, we tested if plasma can kill these bacteria without the addition of platelets. Plasma without platelets showed no significant killing (19 $\pm 4 \%)$. The addition of thrombin to plasma resulted in a high killing rate of $84 \pm 17 \%$, which was still significantly below the maximum control shown in fig. 5 ( $\mathrm{p}=0.0011$, Wilcoxon). The inhibition of thrombin activity by hirudin completely aborted bactericidal effects, also the incubation of $B$. subtilis with thrombin alone, without addition of plasma, did not show any significant killing (17 $\pm 8 \%)$. To exclude complement or antibody effects in the killing assay, we also tested the bactericidal effects of serum. But in the presence of serum there was no killing observed with $(18 \pm 7 \%)$ or without the addition of thrombin $(19 \pm 6 \%)$.

\section{Plasma protein fraction $>100 \mathrm{kDa}$ mediates the high killing rates}

To determine the plasma component, which cause the high killing rates, we fractionated the plasma proteins with two filters in the MW ranges $>10 \mathrm{kDa},<10 \mathrm{kDa},>100 \mathrm{kDa}$ and $<100 \mathrm{kDa}$ and tested the killing rates after addition of these fractions to gel-filtered platelets. It was determined, that the fraction $>100 \mathrm{kDa}$ was responsible for a killing as high as $91 \pm 8 \%$. The effects of the fractions $>100 \mathrm{kDa}$ and $>10 \mathrm{kDa}$ were not significantly different from killing rates in normal plasma (max-control), which reached $95 \pm 5 \%(\mathrm{p}=0.34$, Wilcoxon). In contrast, the fractions $<100 \mathrm{kDa}$ showed a decreased killing of $33 \pm 8 \%$ and the fraction $<10 \mathrm{kDa}$ reached only $19 \pm 8 \%$ (Fig. 6).

\section{Thrombin interaction with platelet receptors is not responsible for killing $B$. subtilis} In our experiments thrombin was always crucial for killing of B. subtilis. Therefore we studied which effect of thrombin was responsible for the observed killing. Thrombin activates human platelets via the protease activating receptors (PAR) 1 and 4 . We dissected these effects by using the synthetic thrombin receptor agonists SFLLRN (SF) for activating the platelet PAR 1 and GYPGKF (GYP) for activating PAR 4. SF reached a maximum killing of $39 \pm 19 \%$, whereas GYP achieved a maximum killing of $34 \pm 20 \%$. Both activators together yielded a killing rate of $41 \pm 20 \%$. To mimic the proteolytical function of thrombin, we also used trypsin in killing experiments. Trypsin reached a significant higher killing rate compared 
to GYP or SF with a killing of $56 \pm 16 \%$, but did not achieve the killing rate that was observed upon thrombin stimulation $(83 \pm 19 \%)$. 


\section{Storage and processing of bactericidal proteins}

In 1960 Hirsch et al. [40] demonstrated bactericidal activities of rabbit serum that are not present prior to clotting. He noticed that plasma regains its bactericidal effect after addition of platelets but not after addition of leukocytes or erythrocytes. Investigations on that subject were intensified in the 1970`s. Donaldson et al. [41-43] isolated $\beta$-lysin as one bactericidal protein, which is stored in rabbit platelets at high concentrations but also occurs to a lower extend in human platelets. Since then several authors focussed on isolating the supposed bactericidal proteins derived from platelets. Nachman et al. [4;44] and the group leaded by Yeaman [45-48] isolated and characterized platelet microbicidal proteins in rabbits. Later on Krijgsveld et al. described analogous bactericidal proteins in human platelets that are released upon thrombin stimulation [13]. Surprisingly, these proteins differ from not bactericidal proteins by a proteolytical truncation of only 2 amino acids. The possibility exist, that thrombin or other extracellular proteases cleave a precursor protein, which contributes to the generation of bactericidal proteins [2]. According to these findings, Tang et al. [14] could identify more bactericidal proteins in human platelets, but two of them are only present in stimulated platelets.

In our model of killing of $B$. subtilis, however, several lines of evidence militate against a main role of bactericidal proteins. Platelet releasates, in our hands, only exert moderate killing effects [9], and we observed a massive killing of bacteria with thrombin-stimulated platelets at about 100fold lower platelet concentrations in comparison to Krijgsveld et al.[13]. Moreover, in earlier investigations we could show, that even completely degranulated platelets have bactericidal capacity [9]. A possible explanation for these conflicting data on bactericidal activity of platelet releasates is presented by Tang et al. [14], who supposed an inhibiting effect of sodium phosphate which is used in most buffer systems. 


\section{Phagocytosis}

Lewis et al. [49] demonstrated for the first time that platelets really phagocytose small particles $(<0.1 \mu \mathrm{m})$, which means that lysosomes fuse with the phagosome and no luminal continuity exists to the outer space. Latex particles were endocytosed through the OCS and reached the cytoplasm in small vesicles. But this way of ingestion is doubtful for bacteria with its much larger size $(2 \mu \mathrm{m})$. Resuming the works of decades, Clawson found no evidences for a real phagocytosis of bacteria [3]. He observed that stimulated platelets recruit other platelets and the growing platelet aggregate surrounds initially adhered bacteria. There they are well separated from the surrounding media and usually appear within interspaces. But really engulfed bacteria are rarely to be seen in platelets [50]. Although granule secretion at plateletbacteria binding sites was observed, no killing of bacteria was described [3]. That is contrary to our investigations. Youssefian et al. [51] postulated an engulfment of Staphylococcus aureus in platelets, which is enhanced after stimulation. But he did not point out that killing occurs after engulfing. From White's updated point of view, bacteria are too big to be actively and completely enclosed within platelets. Therefore platelets may just cover bacteria as "covercytes" to separate this foreign material from the blood stream in vivo [16].

\section{Synthesis of reactive oxygen species}

After phagocytosis by neutrophils, ROS play an important role in the definitive killing of pathogens. Several clues exist that also platelet-derived ROS could be engaged in host defense: ROS-dependent cytocidal effects were described in the platelet-mediated killing of helminths [52], ruffled platelet membranes were observed at bacteria binding sites [9], and a decreased killing of bacteria was observed to occur in the presence of antioxidants (own unpublished data). Thus we tried to establish the role of ROS in killing B. subtilis by platelets. The term ROS contains several molecular species with different properties. The key role has superoxide anion $\left(\mathrm{O}_{2}^{-}\right)$as the first molecule in the complete reaction chain. Being unstable, it is converted to peroxynitrite or by superoxide dismutase (SOD) to hydrogen peroxide $\left(\mathrm{H}_{2} \mathrm{O}_{2}\right)$. $\mathrm{H}_{2} \mathrm{O}_{2}$ itself is strongly bactericidal and can be further converted into other bactericidal oxygen species. In 1977, Marcus et al.[53] found superoxide $\left(\mathrm{O}_{2}{ }^{-}\right)$production and in 1982 FinazziAgro et al. [54] could detect hydrogen peroxide $\left(\mathrm{H}_{2} \mathrm{O}_{2}\right)$ release from platelets. First hints that platelet-derived ROS have cytocidal effects was given by Joseph et al. in IgEmediated killing of helminths [52;55]. This hypothesis is aided by our findings of ruffled membranes at platelet-bacteria binding sites which suggested similarities to ROS generating neutrophils [27] and osteoclasts [28]. In these cells, ruffled membranes are generated by actin 
polymerization and become sites of assembly of the NAD $(\mathrm{P}) \mathrm{H}$-oxidase complex. In this way, neutrophils and osteoclasts produce locally restricted large quantities of ROS to kill bacteria or to remodel the bone matrix. In addition to ruffled membranes, we observed a decreased killing rate by addition of the antioxidant vitamin $\mathrm{E}$ ( $\alpha$-tocopherol) in earlier investigations in our laboratory (unpublished data).

Based on these reports and observations, we assumed a possible role for platelet-derived ROS in our bactericidal model. We focussed in our experiments on detecting the release of $\mathrm{O}_{2}{ }^{-}$and $\mathrm{H}_{2} \mathrm{O}_{2}$ quantitatively as well as topologically, and we studied the influence of stimulation and inhibition of ROS-synthesis on the resulting killing rates.

B. subtilis is highly susceptible to the killing abilities of thrombin-stimulated platelets. It is a Gram- and catalase-positive bacterium, which has 3 catalases [39], and it should be well protected against the cytocidal effects of $\mathrm{H}_{2} \mathrm{O}_{2}$. In our experiments we detected that one platelet does produce about 1500 times less superoxide and 4000 times less $\mathrm{H}_{2} \mathrm{O}_{2}$ compared to one neutrophil. Although the concentration of platelets in native blood is 30 times higher and under our experimental conditions even 100- 500fold higher than the physiological concentration of neutrophils, the detected ROS release does not reach bactericidal dimensions for B. subtilis at all. Consistent with your observation that $50 \mathrm{mM} \mathrm{H}_{2} \mathrm{O}_{2}$ kills $25 \%$ of B. subtilis within $10 \mathrm{~min}$, Murphy et al. demonstrated that $10 \mathrm{mM} \mathrm{H}_{2} \mathrm{O}_{2}$ is enough to kill almost all B. subtilis by a longer incubation time of $1 \mathrm{~h}[56]$.

The detection of very low levels of ROS with subsequent high standard deviations and the disappointing weak reaction to stimulators led us to the assumption, that aggregated platelets can not release all generated ROS into the supernatant. In this way, freshly synthesized ROS inside a platelet aggregate will be converted before it will be detected in the supernatant. That might explain the low ROS detection when strong aggregating agents like thrombin were used.

Another critical factor in the ROS assay is that the isolation process prestimulates platelets in a donor-dependent fashion, so that it is difficult to further increase ROS production with stimulators. Low amounts and prestimulated, aggregated platelets hamper the exact quantification of ROS release. Another delicate point is that platelet concentrates are not totally free of neutrophils. To assure about the cellular source of ROS (neutrophils or platelets), we used a direct local detection of ROS in addition to the cytochrom $\mathrm{C}$ or phenolred/peroxidase assays. Both electron and fluorescence microscopy revealed that no locally restricted ROS synthesis could be found at platelet-bacteria binding sites. In contrast 
to that, neutrophils show a strong ROS production as visualized with both microscopical methods, whereas in platelets nearly no detection of $\mathrm{H}_{2} \mathrm{O}_{2}$ is possible.

Finally we investigated and compared the killing effects of PMA- and thrombin-stimulated platelets to determine the role of ROS in killing B. subtilis. Stimulation by PMA yields only a moderate killing rate after prolonged time compared to platelet stimulation by thrombin, which kill with high efficiency within a few minutes. Furthermore we preincubated platelets with $\mathrm{DPI}$, an unspecific inhibitor of $\mathrm{NAD}(\mathrm{P}) \mathrm{H}$-oxidase in neutrophils. DPI preincubated platelets do change their thrombin-dependent killing of bacteria partially. Hence neither PMA did increase the killing of $B$. subtilis nor did DPI inhibit the enormous thrombin-mediated killing clearly.

So until now, neither bactericidal peptides nor phagocytosis or ROS release can explain the mechanism of platelet-mediated bactericidal action, and we have to conclude that the platelets obviously have learned not enough from their big brothers, the granulocytes. But what establishes their bactericidal activity, which is clearly observed both in vitro and in vivo? Platelets might have found their own way, to participate in host defense.

\section{Role of Thrombin and Plasma Proteins}

In all experiments it was remarkable that the presence of plasma as well as a stimulation by thrombin was essential to kill B. subtilis. Gel-filtered and thrombin-stimulated platelets showed no killing effects until at least a portion of $20 \%$ plasma was added. In contrast, heatinactivated plasma, a plasma protein fraction $<100 \mathrm{kDa}$, serum or thrombin alone offered no killing potential. Therefore complement or antibody action in that killing can be excluded, because these components are also present in the serum.

Furthermore, the action of thrombin was mimicked by the synthetic thrombin receptor agonists SFLLRN or GYPGKF, which stimulated the platelets without having any proteolytic effects [32;33]. Although the platelets were activated and degranulated, no remarkable killing of B. subtils occured.

In conclusion, the observed bactericidal effects do not seem to be mainly due to an active contribution of platelets, like bactericidal peptides, the production of ROS or phagocytosis. The present work rather suggests that platelets contribute to the innate host defense by providing a catalytical surface for synthesis of thrombin. Thrombin was always added in our in-vitro experiments, but can be generated in vivo only in close contact to the platelet surface. Inhibition of thrombin by hirudin completely abolishes all bactericidal activity of plasma in our experiments. In the presence of a heat-instable plasma protein with a MW > $100 \mathrm{kDa}$, the 


\section{Acknowledgements}

This work was supported by the Deutsche Forschungsgemeinschaft (GRK 288).

We want to thank Dr. P. Schlenke and Dr. S. Görg from the Institute of Immunology and Transfusion Medicine at the University of Lübeck for providing us with platelet concentrates and buffy coats. The excellent technical assistance by Tine Asmus, Kerstin Fibelkorn and Jutta Endler is gratefully acknowledged.

The authors have declared no conflict of interest. 


\section{References}

[1] Klinger MH, Jelkmann W: Role of blood platelets in infection and inflammation. $J$ Interferon Cytokine Res 2002, 22, 913-922.

[2] Yeaman MR, Bayer AS: Antimicrobial host defense; in Michelson AD (ed): Platelets. London, Academic Press, 2002, pp 469-482.

[3] Clawson CC: Platelets in bactericidal infections; in Joseph M (ed):

Immunopaharmacology of platelets. London, Academic Press, 1995, pp 83-124.

[4] Nachman RL, Weksler B: The platelet as an inflammatory cell. Ann N Y Acad Sci 1972, 201, 131-137.

[5] Simonet M, Triadou P, Frehel C, Morel-Kopp MC, Kaplan C, Berche P: Human platelet aggregation by Yersinia pseudotuberculosis is mediated by invasin. Infect Immun 1992, 60, 366-373.

[6] Alugupalli KR, Michelson AD, Barnard MR, Robbins D, Coburn J, Baker EK, Ginsberg MH, Schwan TG, Leong JM: Platelet activation by a relapsing fever spirochaete results in enhanced bacterium-platelet interaction via integrin alphaIIbbeta3 activation. Mol Microbiol 2001, 39, 330-340.

[7] Herzberg MC, Gong K: Platelets and bacterial infections; in Gresele P, Page C, Fuster $\mathrm{V}$, Vermylen J (eds): Platelets in thrombotic and non-thrombotic disorders. Cambridge, Cambridge - University Press, 2002, pp 783-805.

[8] Dankert J, van Der WJ, Zaat SA, Joldersma W, Klein D, Hess J: Involvement of bactericidal factors from thrombin-stimulated platelets in clearance of adherent viridans streptococci in experimental infective endocarditis. Infect Immun 1995, 63, 663-671.

[9] Klinger M, Ulbricht T: Participation of human blood platelets in antimicrobial host defense. Transfus Med Hemother 2003, 30, 57-62.

[10] Clawson CC, White JG, Herzberg MC: Platelet interaction with bacteria. VI. contrasting the role of fibrinogen and fibronectin. Am J Hematol 1980, 9, 43-53.

[11] Fodor j: Die Fähigkeit des Blutes Bakterien zu vernichten. Dtsch Med Wochenschau $1887,13,745-747$.

[12] Yeaman MR, Tang YQ, Shen AJ, Bayer AS, Selsted ME: Purification and in vitro activities of rabbit platelet microbicidal proteins. Infect Immun 1997, 65, 1023-1031. 
[13] Krijgsveld J, Zaat SA, Meeldijk J, van Veelen PA, Fang G, Poolman B, Brandt E, Ehlert JE, Kuijpers AJ, Engbers GH, Feijen J, Dankert J: Thrombocidins, microbicidal proteins from human blood platelets, are C-terminal deletion products of CXC chemokines. J Biol Chem 2000, 275, 20374-20381.

[14] Tang YQ, Yeaman MR, Selsted ME: Antimicrobial peptides from human platelets. Infect Immun 2002, 70, 6524-6533.

[15] Meseguer J, Esteban MA, Rodriguez A: Are thrombocytes and platelets true phagocytes? Microsc Res Tech 2002, 57, 491-497.

[16] White JG: Platelets are covercytes, not phagocytes: uptake of bacteria involves channels of the open canalicular system. Platelets 2005, 16, 121-131.

[17] Krotz F, Sohn HY, Pohl U: Reactive oxygen species: players in the platelet game. Arterioscler Thromb Vasc Biol 2004, 24, 1988-1996.

[18] Maresca M, Colao C, Leoncini G: Generation of hydrogen peroxide in resting and activated platelets. Cell Biochem Funct 1992, 10, 79-85.

[19] Krotz F, Sohn HY, Gloe T, Zahler S, Riexinger T, Schiele TM, Becker BF, Theisen K, Klauss V, Pohl U: NAD(P)H oxidase-dependent platelet superoxide anion release increases platelet recruitment. Blood 2002, 100, 917-924.

[20] Wachowicz B, Olas B, Zbikowska HM, Buczynski A: Generation of reactive oxygen species in blood platelets. Platelets 2002, 13, 175-182.

[21] Leo R, Pratico D, Iuliano L, Pulcinelli FM, Ghiselli A, Pignatelli P, Colavita AR, FitzGerald GA, Violi F: Platelet activation by superoxide anion and hydroxyl radicals intrinsically generated by platelets that had undergone anoxia and then reoxygenated. Circulation 1997, 95, 885-891.

[22] Caccese D, Pratico D, Ghiselli A, Natoli S, Pignatelli P, Sanguigni V, Iuliano L, Violi F: Superoxide anion and hydroxyl radical release by collagen-induced platelet aggregation--role of arachidonic acid metabolism. Thromb Haemost 2000, 83, 485490.

[23] Pignatelli P, Pulcinelli FM, Lenti L, Gazzaniga PP, Violi F: Hydrogen peroxide is involved in collagen-induced platelet activation. Blood 1998, 91, 484-490.

[24] Sanner BM, Meder U, Zidek W, Tepel M: Effects of glucocorticoids on generation of reactive oxygen species in platelets. Steroids 2002, 67, 715-719.

[25] Babior BM, Kipnes RS, Curnutte JT: Biological defense mechanisms. The production by leukocytes of superoxide, a potential bactericidal agent. J Clin Invest 1973, 52, 741-744. 
[26] Jandl RC, ndre-Schwartz J, Borges-DuBois L, Kipnes RS, McMurrich BJ, Babior BM: Termination of the respiratory burst in human neutrophils. J Clin Invest 1978, 61, 1176-1185.

[27] Robinson JM, Badwey JA: The NADPH oxidase complex of phagocytic leukocytes: a biochemical and cytochemical view. Histochem Cell Biol 1995, 103, 163-180.

[28] Key LL, Jr., Wolf WC, Gundberg CM, Ries WL: Superoxide and bone resorption. Bone 1994, 15, 431-436.

[29] Vu TK, Hung DT, Wheaton VI, Coughlin SR: Molecular cloning of a functional thrombin receptor reveals a novel proteolytic mechanism of receptor activation. Cell 1991, 64, 1057-1068.

[30] Xu WF, Andersen H, Whitmore TE, Presnell SR, Yee DP, Ching A, Gilbert T, Davie EW, Foster DC: Cloning and characterization of human protease-activated receptor 4. Proc Natl Acad Sci USA 1998, 95, 6642-6646.

[31] Blomback B, Blomback M, Hessel B, Iwanaga S: Structure of N-terminal fragments of fibrinogen and specificity of thrombin. Nature 1967, 215, 1445-1448.

[32] Dohlman HG, Thorner J, Caron MG, Lefkowitz RJ: Model systems for the study of seven-transmembrane-segment receptors. Annu Rev Biochem 1991, 60, 653-688.

[33] Hollenberg MD, Compton SJ: International Union of Pharmacology. XXVIII. Proteinase-activated receptors. Pharmacol Rev 2002, 54, 203-217.

[34] Cabanis A, Gressier B, Lebegue S, Brunet C, Dine T, Luyckx M, Cazin M, Cazin JC: A rapid density gradient technique for separating polymorphonuclear granulocytes. APMIS 1994, 102, 119-121.

[35] Timmons S, Hawiger J: Isolation of Platelets; in Methods of Enzymology Vol 169. San Diego, Academic Press, 1989, pp 11-21.

[36] Briggs RT, Drath DB, Karnovsky ML, Karnovsky MJ: Localization of NADH oxidase on the surface of human polymorphonuclear leukocytes by a new cytochemical method. J Cell Biol 1975, 67, 566-586.

[37] Telek G, Scoazec JY, Chariot J, Ducroc R, Feldmann G, Roz C: Cerium-based histochemical demonstration of oxidative stress in taurocholate-induced acute pancreatitis in rats. A confocal laser scanning microscopic study. J Histochem Cytochem 1999, 47, 1201-1212.

[38] Repine JE, White JG, Clawson CC, Holmes BM: The influence of phorbol myristate acetate on oxygen consumption by polymorphonuclear leukocytes. J Lab Clin Med 1974, 83, 911-920. 
[39] Loewen PC, Switala J: Multiple catalases in Bacillus subtilis. J Bacteriol 1987, 169, 3601-3607.

[40] Hirsch JG: Comparative bactericidal activities of blood serum and plasma serum. $J$ Exp Med 1960, 112, 15-22.

[41] Donaldson DM, Tew JG: beta-Lysin of platelet origin. Bacteriol Rev 1977, 41, 501513.

[42] Roberts RR, Tew JG, Donaldson DM: Release of beta-lysin from platelets caused by antigen-antibody complexes, purified enzymes, and platelet-aggregating substances. Infect Immun 1977, 15, 485-490.

[43] Tew JG, Roberts RR, Donaldson DM: Release of beta-lysin from platelets by thrombin and by a factor produced in heparinized blood. Infect Immun 1974, 9, 179186.

[44] Weksler BB, Nachman RL: Rabbit platelet bactericidal protein. J Exp Med 1971, 134, 1114-1130.

[45] Yeaman MR, Tang YQ, Shen AJ, Bayer AS, Selsted ME: Purification and in vitro activities of rabbit platelet microbicidal proteins. Infect Immun 1997, 65, 1023-1031.

[46] Yeaman MR, Puentes SM, Norman DC, Bayer AS: Partial characterization and staphylocidal activity of thrombin-induced platelet microbicidal protein. Infect Immun 1992, 60, 1202-1209.

[47] Yeaman MR, Norman DC, Bayer AS: Platelet microbicidal protein enhances antibiotic-induced killing of and postantibiotic effect in Staphylococcus aureus. Antimicrob Agents Chemother 1992, 36, 1665-1670.

[48] Yeaman MR, Norman DC, Bayer AS: Staphylococcus aureus susceptibility to thrombin-induced platelet microbicidal protein is independent of platelet adherence and aggregation in vitro. Infect Immun 1992, 60, 2368-2374.

[49] Lewis JC, Maldonado JE, Mann KG: Phagocytosis in human platelets: localization of acid phosphatase-positive phagosomes following latex uptake. Blood 1976, 47, 833840.

[50] Clawson CC, Repine JE: Proceedings: Products of platelet aggregation and release as a chemotactic factor for human leucocytes. Thromb Diath Haemorrh 1975, 34, 603.

[51] Youssefian T, Drouin A, Masse JM, Guichard J, Cramer EM: Host defense role of platelets: engulfment of HIV and Staphylococcus aureus occurs in a specific subcellular compartment and is enhanced by platelet activation. Blood 2002, 99, 40214029 . 
[52] Joseph M, Auriault C, Capron M, Ameisen JC, Pancre V, Torpier G, Kusnierz JP, Ovlaque G, Capron A: IgE-dependent platelet cytotoxicity against helminths. Adv Exp Med Biol 1985, 184, 23-33.

[53] Marcus AJ, Silk ST, Safier LB, Ullman HL: Superoxide production and reducing activity in human platelets. J Clin Invest 1977, 59, 149-158.

[54] Finazzi-Agro A, Menichelli A, Persiani M, Biancini G, Del PD: Hydrogen peroxide release from human blood platelets. Biochim Biophys Acta 1982, 718, 21-25.

[55] Tran A, Vanhee D, Capron A, Vorng H, Braquet P, Joseph M: Separate induction of human blood platelet aggregation or cytotoxicity by different concentrations of PAFacether and thrombin. Agents Actions 1992, 36, 39-43.

[56] Murphy P, Dowds BC, McConnell DJ, Devine KM: Oxidative stress and growth temperature in Bacillus subtilis. J Bacteriol 1987, 169, 5766-5770.

[57] Sullam PM, Frank U, Yeaman MR, Tauber MG, Bayer AS, Chambers HF: Effect of thrombocytopenia on the early course of streptococcal endocarditis. J Infect Dis 1993, $168,910-914$.

[58] Bayer AS, Cheng D, Yeaman MR, Corey GR, McClelland RS, Harrel LJ, Fowler VG, Jr.: In vitro resistance to thrombin-induced platelet microbicidal protein among clinical bacteremic isolates of Staphylococcus aureus correlates with an endovascular infectious source. Antimicrob Agents Chemother 1998, 42, 3169-3172.

[59] Mercier RC, Rybak MJ, Bayer AS, Yeaman MR: Influence of platelets and platelet microbicidal protein susceptibility on the fate of Staphylococcus aureus in an in vitro model of infective endocarditis. Infect Immun 2000, 68, 4699-4705.

[60] Kupferwasser LI, Yeaman MR, Shapiro SM, Nast CC, Bayer AS: In vitro susceptibility to thrombin-induced platelet microbicidal protein is associated with reduced disease progression and complication rates in experimental Staphylococcus aureus endocarditis: microbiological, histopathologic, and echocardiographic analyses. Circulation 2002, 105, 746-752.

[61] Feldman C, Kallenbach JM, Levy H, Thorburn JR, Hurwitz MD, Koornhof HJ: Comparison of bacteraemic community-acquired lobar pneumonia due to Streptococcus pneumoniae and Klebsiella pneumoniae in an intensive care unit. Respiration 1991, 58, 265-270.

[62] Kirkpatrick B, Reeves DS, MacGowan AP: A review of the clinical presentation, laboratory features, antimicrobial therapy and outcome of 77 episodes of pneumococcal meningitis occurring in children and adults. J Infect 1994, 29, 171-182.

[63] Chang FY, Singh N, Gayowski T, Wagener MM, Mietzner SM, Stout JE, Marino IR: Thrombocytopenia in liver transplant recipients: predictors, impact on fungal infections, and role of endogenous thrombopoietin. Transplantation 2000, 69, 70-75. 


\section{Figure legends}

Fig. 1

Release of superoxide anion by platelets (left y axis) and neutrophils (right y axis) following stimulation with PMA and inhibition with DPI. Whereas neutrophils clearly respond to both stimulation and inhibition, the platelets did not react significantly. Calculated onto a per cell basis, a maximum stimulation with PMA induces one neutrophil to release appr. 1500-fold more $\mathrm{O}_{2}{ }^{-}$than one platelet. Thus, release of superoxide anion will not substantially contribute to bactericidal activity of platelets.

Fig. 2

Release of hydrogen peroxide by platelets (left y axis) and neutrophils (right y axis) following stimulation with PMA or inhibition with DPI. Both cells significantly react on the maximum stimulus (Asterisks; $\mathrm{p}<0.05$; Wilcoxon), but platelets fail to further enhance their hydrogen peroxide release after addition of SOD. Calculated onto a per cell basis, a maximum stimulation with PMA induces one neutrophil to release appr. 4000-fold more $\mathrm{H}_{2} \mathrm{O}_{2}$ than one platelet. Thus, release of hydrogen peroxide will not substantially contribute to bactericidal activity of platelets.

Fig. 3

Topological fluorescence analysis of hydrogen peroxide release following PMA stimulation of neutrophils (A) and platelets (B). In neutrophils, the circumferentially located phagolysosomes release a strong signal, but the fluorescence intensity produced by aggregated platelets is very weak and does not show local enrichment of the signal, thus not supporting a role of hydrogen peroxide in the killing of bacteria by platelets.

Bars: $5 \mu \mathrm{m}$ 
Fig. 4 A - D

Electron microscopical detection of neutrophil hydrogen peroxide release by precipitation of cerium perhydroxide. Stimulation of neutrophils with PMA induces precipitation on the outer cell membran and also on the inner aspect of vacuoles (arrows in A). Addition of catalase totally abolishes the precipitation, thereby confirming the specificity of the reaction (B). Unstimulated neutrophils display crystals only at a few sites (C). At higher magnification, precipitation (arrow) can be detected close to ingested bacteria (Bs).

Bars: $1 \mu \mathrm{m}$

Fig. 4 E - H

Electron microscopical detection of platelet hydrogen peroxide release by precipitation of cerium perhydroxide. Neither stimulation with PMA (A), nor stimulation in the presence of catalase (B), control platelets (C) or ingestion of bacteria (D; Bs) lead to any precipitation of cerium perhydroxide. Thus, the assumption of a local enrichment of reactive oxygen species is not supported.

Bars: $1 \mu \mathrm{m}$

Fig. 5

Killing of bacteria by stimulated platelets. Whereas stimulation of platelets with thrombin leads to nearly complete killing already after $10 \mathrm{~min}$, stimulation with PMA only induces moderate killing rates after 20 and more min.

Asterisks: Significantly higher killing rates compared to the baseline value $(\mathrm{p}<0.01$;

Wilcoxon) 
Fig. 6

Killing of bacteria by thrombin-stimulated platelets is dependent from the presence of blood plasma components. Gel-filtered platelets resuspended in buffer excert a comparable low killing activity like platelets in serum or platelets in plasma without high molecular weight proteins. To achieve a maximum of killing, both the plasma protein fraction above $100 \mathrm{kD}$ and the activity of thrombin are required. 


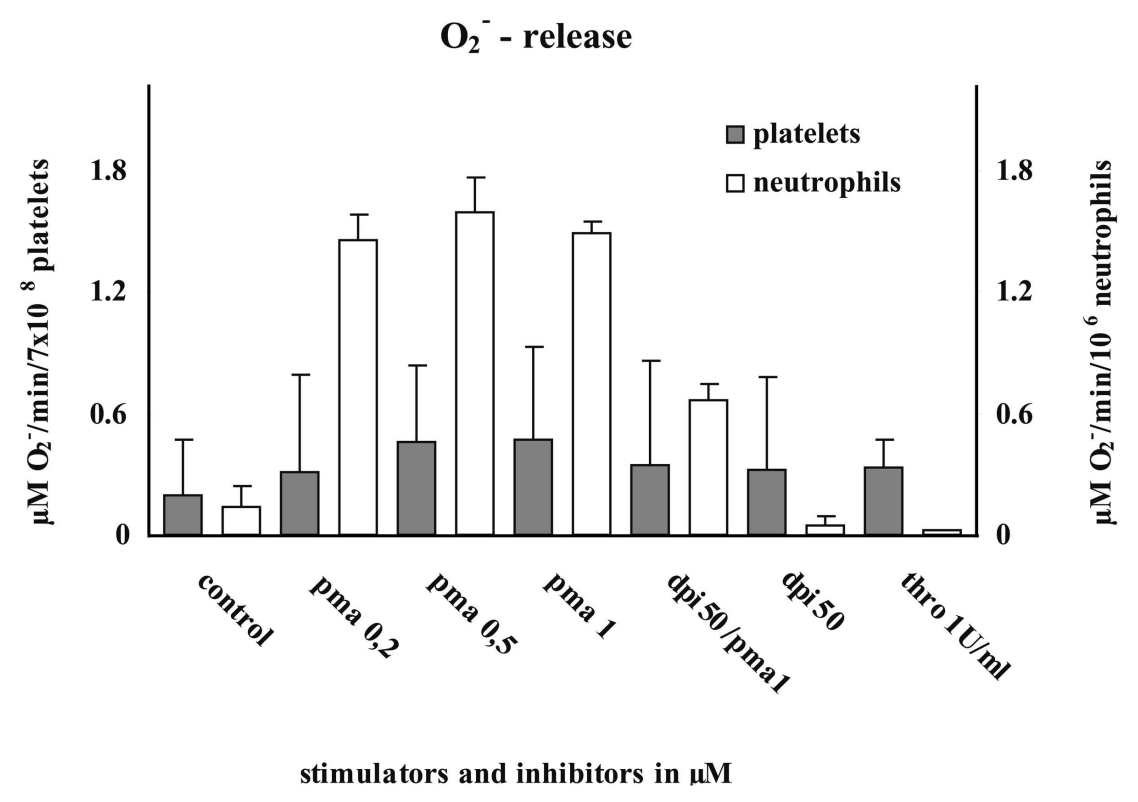

Zander \& Klinger: Fig. 1 $120 \times 76 \mathrm{~mm}(600 \times 600$ DPI $)$ 


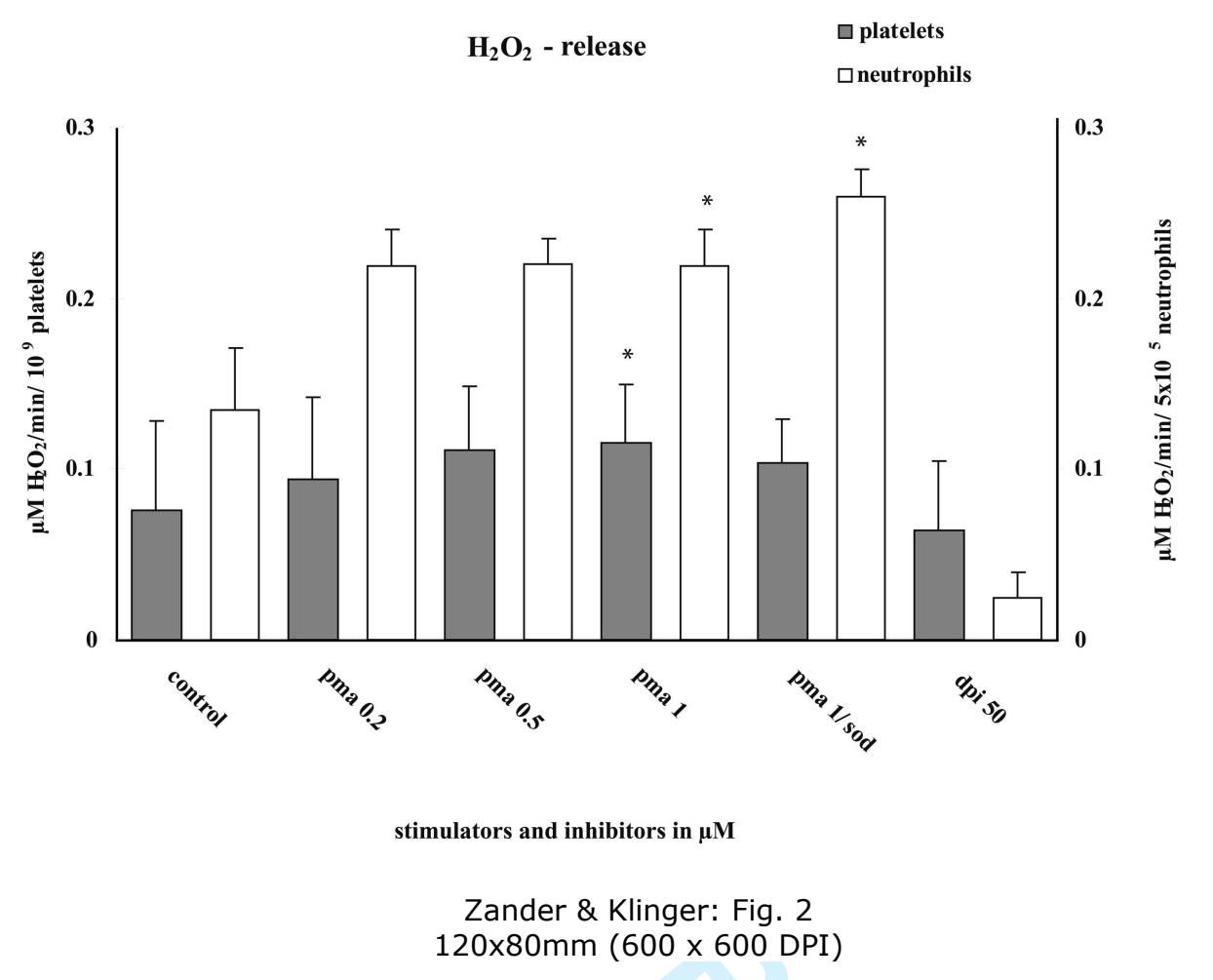

Wiley-VCH 


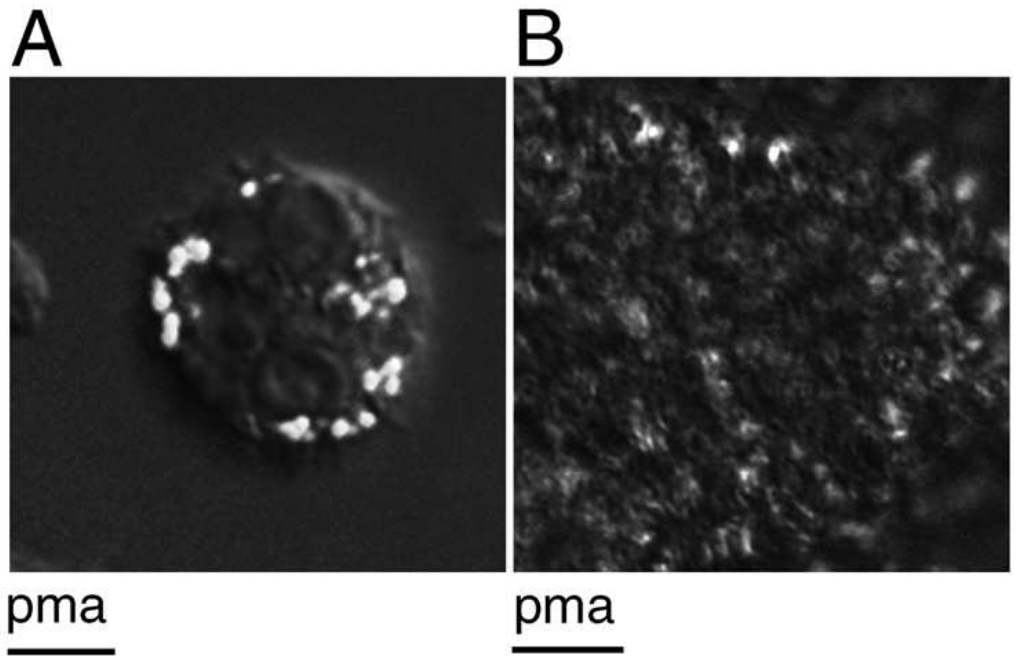

Zander \& Klinger: Fig. 3 $80 \times 46 \mathrm{~mm}$ (300 x 300 DPI) 

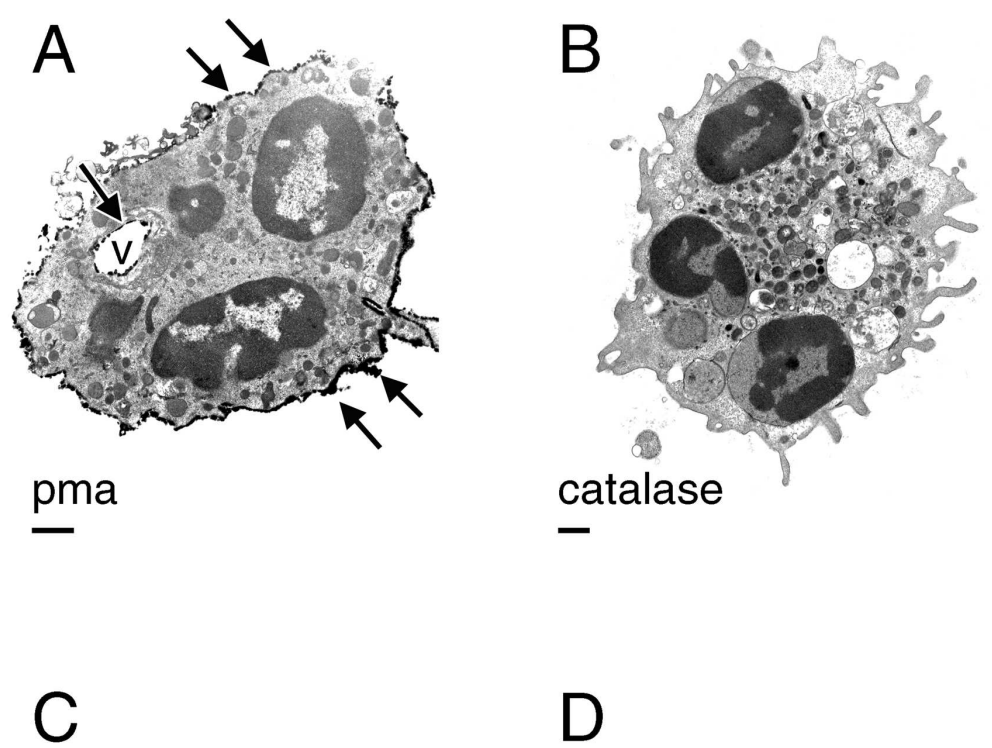

D

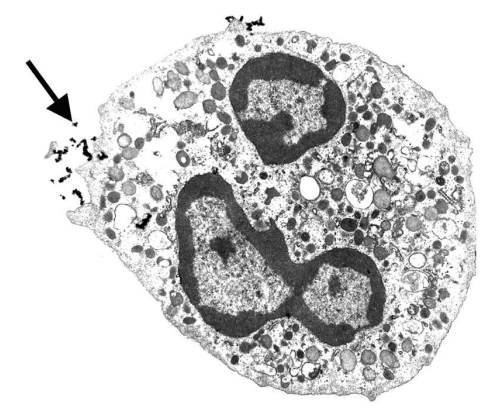

control

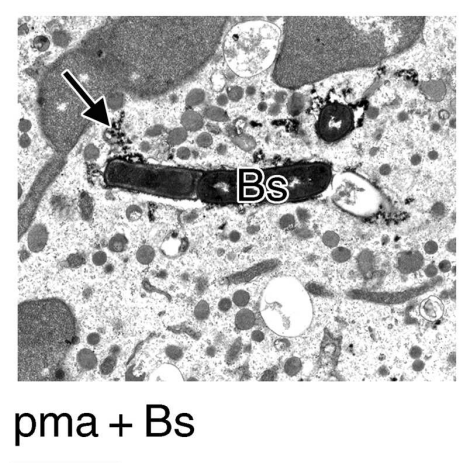

Zander \& Klinger: Fig. 4a-d $160 \times 226 \mathrm{~mm}(300 \times 300$ DPI $)$ 

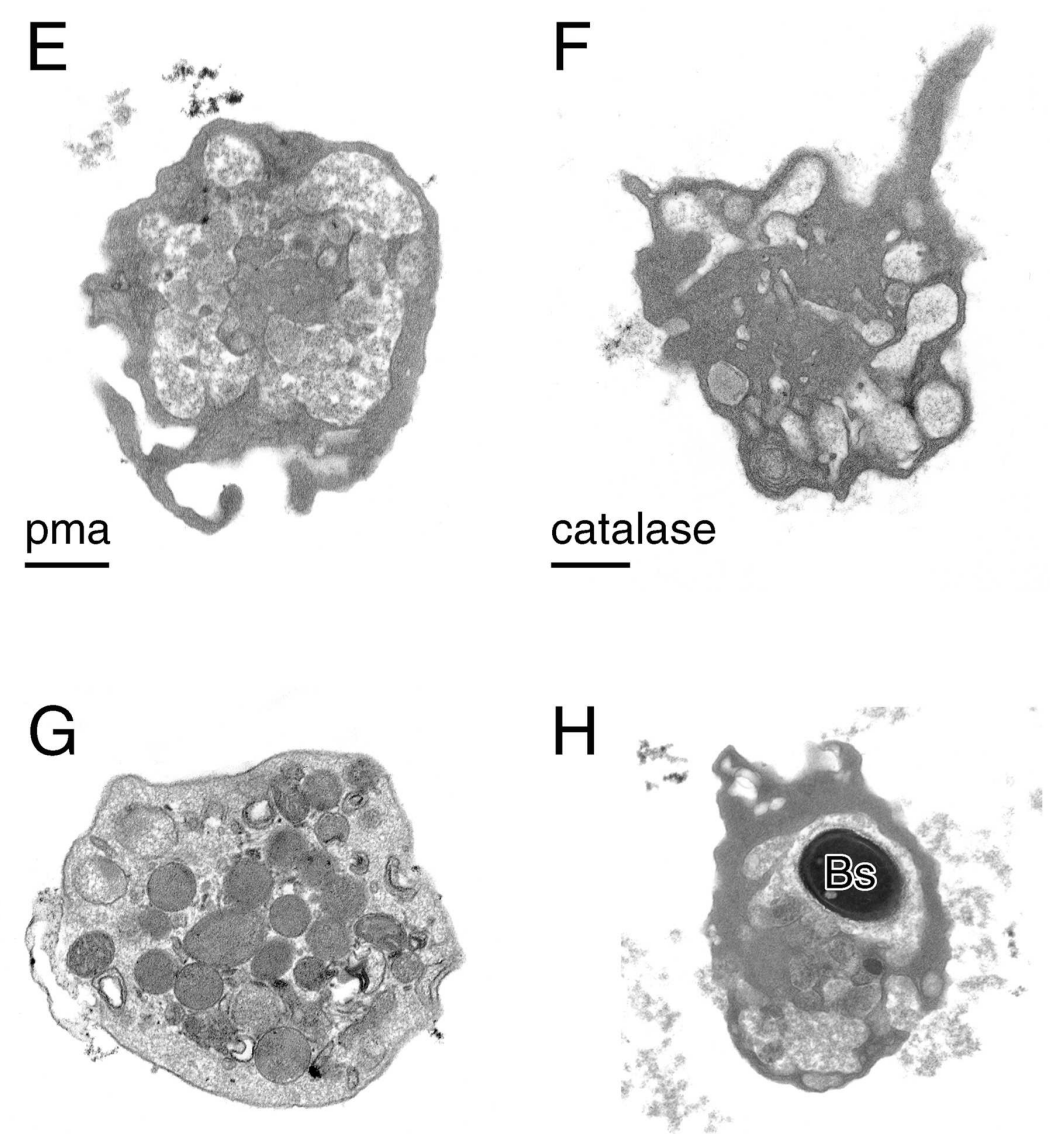

control

$\underline{\mathrm{pma}+\mathrm{Bs}}$

Zander \& KLinger: Fig. 4e-h $160 \times 226 \mathrm{~mm}(300 \times 300 \mathrm{DPI})$ 


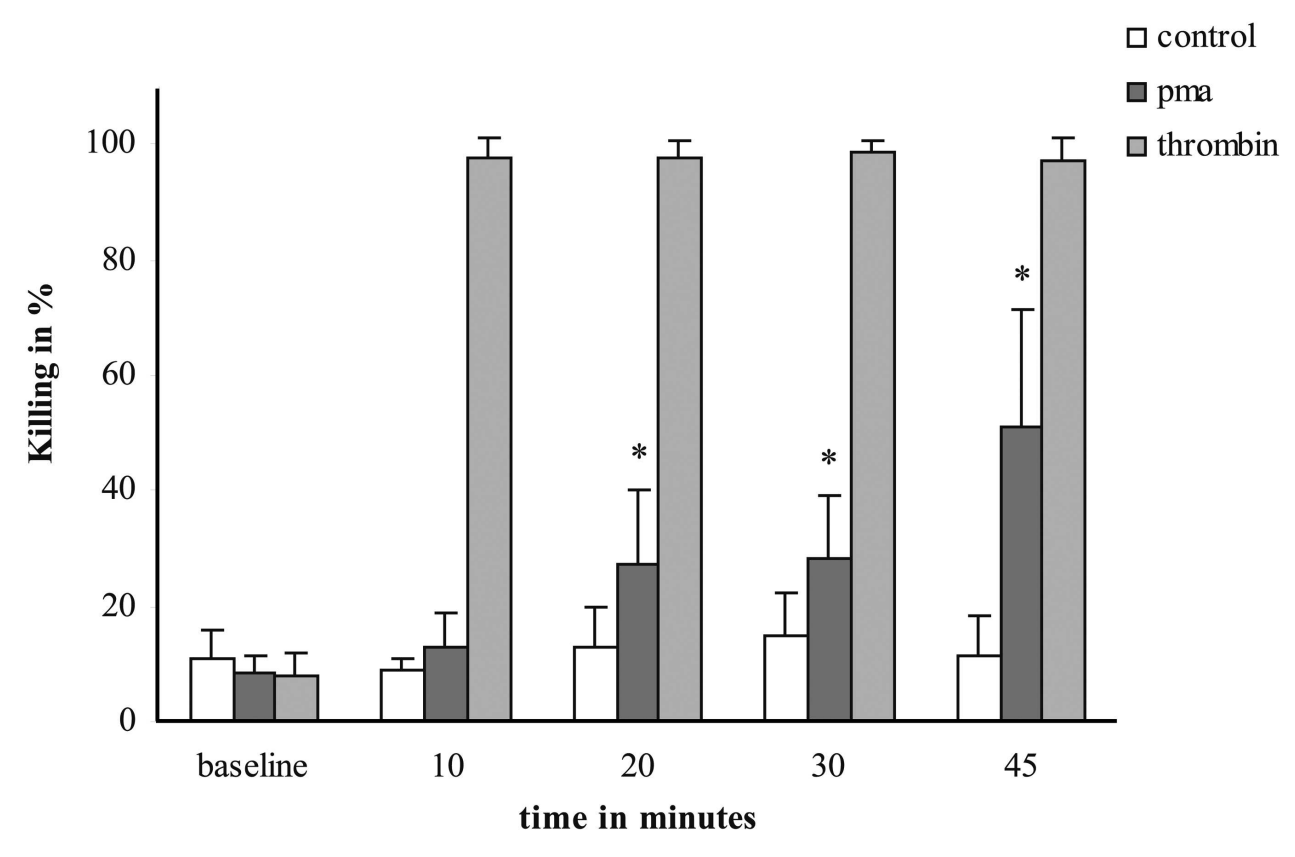

Zander \& Klinger: Fig. 5 $120 \times 80 \mathrm{~mm}(600 \times 600$ DPI $)$ 


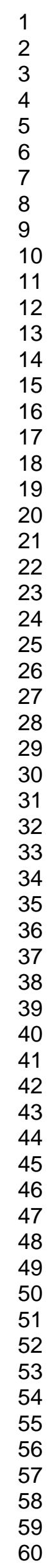

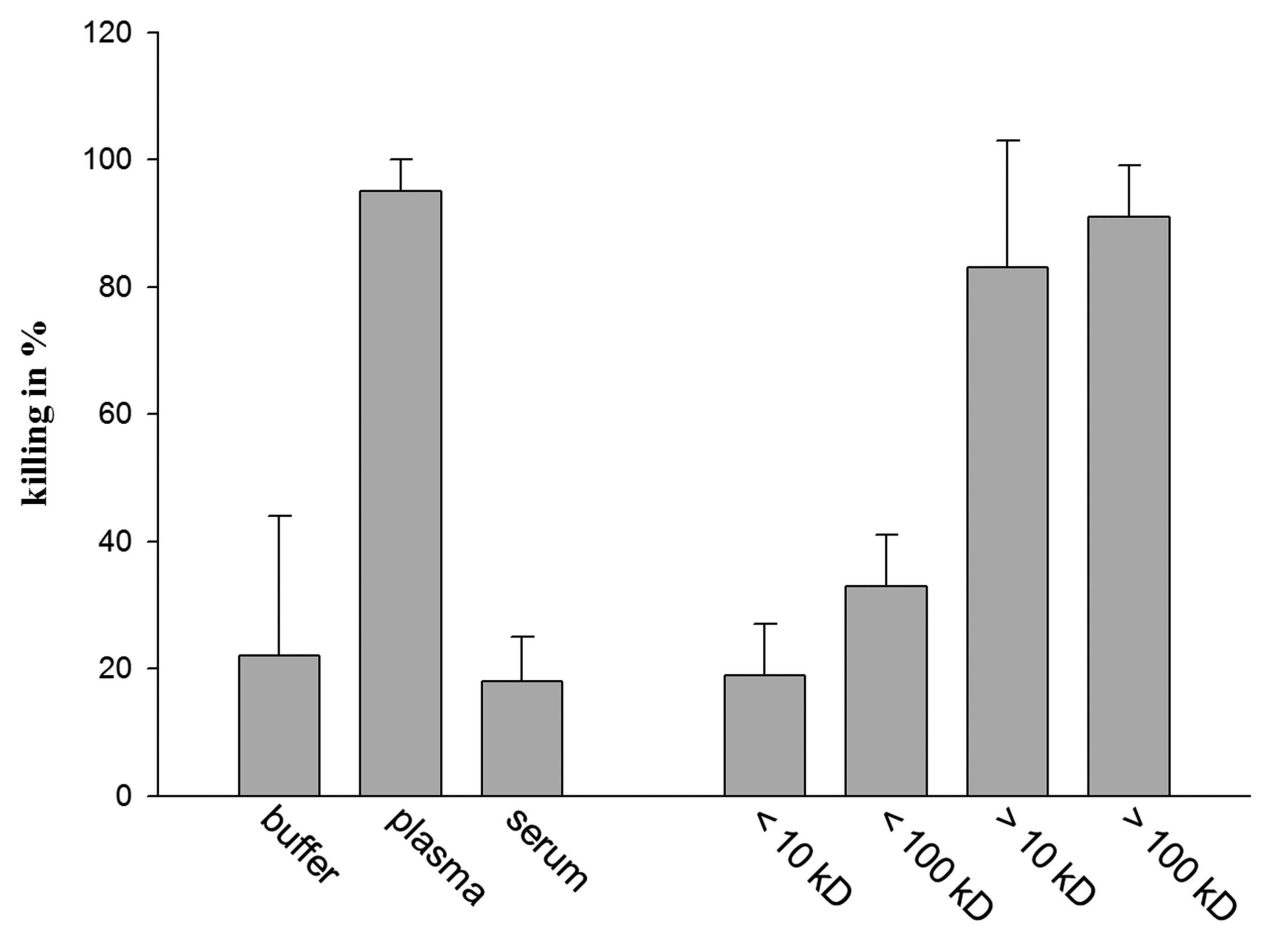

Zander \& Klinger: Fig. 6 $120 \times 90 \mathrm{~mm}(600 \times 600$ DPI $)$ 